DE

M E D I C I N A

T R O P I C A L

$\mathrm{DE}$

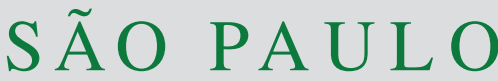

JOURNAL OF THE SÃO PAULO INSTITUTE OF TROPICAL MEDICINE

${ }^{1}$ Hospital Sírio-Libanês, Instituto SírioLibanês de Ensino e Pesquisa, São Paulo, São Paulo, Brazil

${ }^{2}$ Instituto Lauro de Souza Lima, Bauru, São Paulo, Brazil

${ }^{3}$ Universidade de São Paulo, Faculdade de Medicina, Departamento de Moléstias Infecciosas e Parasitárias, São Paulo, São Paulo, Brazil

Correspondence to: Cristiano Soares da Silva

Hospital Sírio-Libanês, Instituto SírioLibanês de Ensino e Pesquisa, R. Prof. Daher Cutait, 69, CEP 01308-060, São Paulo, SP, Brazil

Tel: +55 $63981211332,+5527981544249$

E-mail: cristianosss@ outlook.com

Received: 18 June 2020

Accepted: 1 September 2020

\section{Impact of health interventions on epidemiological and operational leprosy indicators in a hyperendemic municipality of Brazil}

\author{
Cristiano Soares da Silva ${ }^{\circledR}$, Jaison Antônio Barreto², Vivian lida \\ Avelino-Silva ${ }^{\circledR}$, Ana Luiza Bierrenbach ${ }^{1}$
}

\section{ABSTRACT}

The study aimed to analyze the impact of health interventions carried out in the city of Palmas, Brazil, on the epidemiological and operational indicators of leprosy between 2007 and 2017. The intervention consisted of training healthcare personnel on the diagnosis and follow-up of patients and organizing the referral of patients to health units. Estimates of the impact were calculated by taking the differences between indicators reported in two equal periods of 1.5 years pre- and post-intervention, with a transition period of six months. During the study period, the database contained 1,875 notifications, with $66 \%$ of cases diagnosed in the post-intervention period. There was a predominance of males $(52 \%)$; aged 50 years or more $(34.9 \%)$; with mixed ethnicity $(63.5 \%)$. The low level of education was noticeable, with more than half of the cases $(51.7 \%)$ reporting illiteracy or $\leq 7$ years of education. The intervention resulted in an increase in both, epidemiological and operational indicators, suggesting a positive impact of the intervention on leprosy detection and treatment. Our results also emphasize the need for further studies addressing the impact of pragmatic health interventions aiming at controlling and eliminating the disease.

KEYWORDS: Hansen disease. Leprosy. Health services research. Epidemiology. Health indicators.

\section{INTRODUCTION}

Leprosy is a chronic, neglected, and stigmatizing disease caused by Mycobacterium leprae. Despite its low case-fatality rate, leprosy is a highly disabling disease, particularly among patients with long-standing nerve damage ${ }^{1,2}$. It is estimated that 2-3 million people live with physical disabilities and suffer from stigma due to leprosy worldwide. Significant heterogeneities in the prevalence of leprosy are reported across the globe; according to the World Health Organization (WHO), in the first quarter of 2017, there were more than 171,000 prevalent cases of leprosy, with higher occurrence in developing countries. Brazil is the second country in the world in number of cases, contributing with $12 \%$ of diagnoses worldwide in 2016. The country registers an average of one new leprosy case every 12 minutes $^{3}$. However, official reports of leprosy occurrence are likely to be underestimated since only confirmed cases are recorded in surveillance systems.

Leprosy diagnosis is in most cases purely clinical, requiring an experienced provider and detailed medical history and the examination of the patient ${ }^{4}$. Infected and untreated people can still spread the infection and will continue to do so until the transmission chain is completely stopped ${ }^{5-9}$. Therefore, once a patient is 
diagnosed, it is necessary to evaluate all close contacts, in order to identify and treat secondary cases. Adequate treatment requires the characterization of the clinical form of the disease, quantification of skin lesions and affected nerves, in addition to a careful analysis of factors such as weight, age and pregnancy status ${ }^{10}$.

Although curable with the existing antimicrobial therapy, leprosy remains a formidable challenge and a public health problem. The diagnosis is highly dependent on the quality of care and the training skills of healthcare providers. Permanent health education interventions targeting both, providers and the population, aiming at increasing diagnostic capacity, reducing stigma and prejudice, and raising individual awareness, are essential for the disease control ${ }^{4,11}$.

The Tocantins State is classified as hyper-endemic for leprosy in Brazil, with a mean detection rate of 69.13 cases per 100 thousand inhabitants from 2012-2016 ${ }^{12}$. The city of Palmas, capital of Tocantins State, has indicators almost 20 times higher than the national average. Aiming to reduce the number of hidden leprosy cases in the city, the Municipal Health Department and the Public Health Foundation promoted in 2016 the Palmas leprosy-free project ${ }^{12-14}$. This intervention focused on the interdisciplinary training of health care providers, improving diagnostic and clinical skills and promoting comprehensive care, with 131 actions carried out within 524 hours of activity in the field and care for 697 patients during the implantation period. Actions took place in healthcare units, as well as in the communities, and included theoretical-practical classes emphasizing prevention of physical disabilities, training of community health workers, establishment of self-care groups in health facilities and support centers, psychological care, and training of laboratory personnel in the collection and analysis of supplementary exams.

This study aimed to analyze the impact of the Palmas leprosy-free interventions on the epidemiological and operational indicators of leprosy in the city of Palmas.

\section{MATERIALS AND METHODS}

This is an epidemiological, observational study, with descriptive and analytical components of time series using data from the Information System for Notifiable Diseases (SINAN) of the city of Palmas.

To identify the impact of training and interventions from training (multidisciplinary assistance, diagnosis, assessment of disability, active search), the differences between annual or monthly epidemiological and operational indicators were calculated and compared. In order to have two equal periods in number of months before and after the intervention to make a better comparison of the indicators, two equal periods of analysis were defined (Pre and Post intervention), with a transition period in between (where the intervention was still being implemented and therefore had not yet had time to interfere with the indicators):

1) Pre-intervention period: July 2014 to December 2015;

2) Transition period: January 2016 to June 2016;

3) Post-intervention period: July 2016 to December 2017.

The specific type of analysis was chosen according to a preliminary assessment of trend curves of each indicator in the pre-intervention period. As the indicators presented relatively stable time curves, that is, there was no evident upward or downward trend in that period, and the seasonality of both periods was the same (from July to December), a simple comparative analysis could be performed.

Monthly and annual rates of incidence and prevalence were calculated for cases across all ages and for children under 15 years. To obtain the population denominator used in the calculation of monthly rates, an exponential interpolation was carried out using population data of the Brazilian Institute of Geography and Statistics.

Continuous data were represented by medians and $25^{\text {th }}$ and $75^{\text {th }}$ percentiles and compared in between the study periods using the Mann-Whitney test. Categorical data are represented by absolute (n) and relative (\%) frequencies and compared using Pearson's chi-square test or Fisher's exact test, as appropriate. For all analyzes, we used Stata 15 (StataCorp, College Station, TX, USA).

This study was approved by the Ethics and Research Committee of the Teaching and Research Institute of Hospital Sirio-Libanes (CAEE N ${ }^{\circ}$ 2.975.876 of October 2018), with a waiver of the Informed Consent Form. All individual identifiable information was maintained confidential.

\section{Actions performed}

In March 2016, with its own resources from the Unified Health System (SUS), the Palmas Leprosy-free Project was implemented in the city of Palmas - Tocantins (TO), by means of a process of multiprofessional and interdisciplinary training of health professionals aiming at providing comprehensive patients' care. The training process took place through theoretical-practical training aimed at clinical management, diagnosis and the entire line of disease care, with on-the-spot actions, theoreticalpractical training with emphasis on prevention and treatment of physical disabilities, training of community health agents, formation of groups of self-care in Health Units and Family Health Support Centers, psychological assistance and training of laboratories in the collection and 
analysis of complementary exams. Health units were visited at different times, taking into account the number of teams and professionals for each health unit, number of cases under treatment and greater social vulnerability.

After being successfully implemented in the municipality of Palmas, the project was used as an inspiration for the development of the "Innovative Approaches Project to intensify efforts for a Brazil free from Hansen's disease", developed by the Ministry of Health in partnership with the Pan American Health Organization and the Nippon
Foundation of Japan, held in 20 municipalities in Maranhao, Mato Grosso, Para, Pernambuco, Piaui and Tocantins States.

\section{RESULTS}

Epidemiological and clinical profile of cases during the study period

Tables 1 and 2 show that from July 2014 to December 2017, the SINAN database of Palmas registered 1,875

Table 1 - Sociodemographic characteristics of study participants in the three study periods. Comparison of pre and post-intervention periods. Palmas, Tocantins State, July 2014 to December 2017.

\begin{tabular}{|c|c|c|c|c|c|c|c|c|c|}
\hline \multirow[t]{2}{*}{ Characteristic } & \multicolumn{2}{|c|}{$\begin{array}{l}\text { Pre-intervention } \\
\text { period }\end{array}$} & \multicolumn{2}{|c|}{ Transition period } & \multicolumn{2}{|c|}{$\begin{array}{c}\text { Post-intervention } \\
\text { period }\end{array}$} & \multicolumn{2}{|c|}{ Total } & \multirow[t]{2}{*}{$p$-value } \\
\hline & $\mathrm{n}$ & $\%$ & $\mathrm{n}$ & $\%$ & $\mathrm{n}$ & $\%$ & $n$ & $\%$ & \\
\hline Sex & & & & & & & & & $<0.001$ \\
\hline Male & 196 & $62.4 \%$ & 145 & $49.8 \%$ & 631 & $49.6 \%$ & 972 & $52 \%$ & \\
\hline Female & 118 & $37.5 \%$ & 146 & $50.1 \%$ & 639 & $50.3 \%$ & 903 & $48 \%$ & \\
\hline Age groups (years) & & & & & & & & & 0.012 \\
\hline Less than 10 & 16 & $5.1 \%$ & 9 & $3.0 \%$ & 31 & $2.4 \%$ & 56 & $2.9 \%$ & \\
\hline $10-14$ & 8 & $2.5 \%$ & 12 & $4.1 \%$ & 65 & $5.1 \%$ & 85 & $4.5 \%$ & \\
\hline $15-19$ & 15 & $4.7 \%$ & 18 & $6.2 \%$ & 54 & $4.2 \%$ & 87 & $4.6 \%$ & \\
\hline $20-29$ & 43 & $13.6 \%$ & 22 & $7.56 \%$ & 145 & $11.4 \%$ & 210 & $11.2 \%$ & \\
\hline $30-39$ & 72 & $22.9 \%$ & 77 & $26.4 \%$ & 247 & $19.4 \%$ & 369 & $21.1 \%$ & \\
\hline $40-49$ & 52 & $16.5 \%$ & 50 & $12.1 \%$ & 284 & $22.3 \%$ & 386 & $20.5 \%$ & \\
\hline $50+$ & 108 & $34.3 \%$ & 103 & $35.4 \%$ & 444 & $34.9 \%$ & 655 & $34.9 \%$ & \\
\hline Ethnicity / Color & & & & & & & & & 0.004 \\
\hline White & 53 & $16.8 \%$ & 39 & $13.4 \%$ & 190 & $14.9 \%$ & 282 & $15.0 \%$ & \\
\hline Black & 48 & $15.2 \%$ & 39 & $13.4 \%$ & 155 & $12.2 \%$ & 242 & $12.9 \%$ & \\
\hline Yellow & 8 & $2.5 \%$ & 7 & $2.4 \%$ & 114 & $8.9 \%$ & 129 & $6.8 \%$ & \\
\hline Mixed ethnicity & 199 & $63.3 \%$ & 201 & $69.0 \%$ & 792 & $62.3 \%$ & 1192 & $63.5 \%$ & \\
\hline Indigenous & 0 & $0.0 \%$ & 2 & $0.6 \%$ & 2 & $0.1 \%$ & 4 & $0.2 \%$ & \\
\hline Ignored & 6 & $1.9 \%$ & 3 & $1.0 \%$ & 17 & $1.3 \%$ & 26 & $1.3 \%$ & \\
\hline Education (years of study) & & & & & & & & & 0.368 \\
\hline Illiterate & 23 & $7.3 \%$ & 10 & $3.4 \%$ & 63 & $4.9 \%$ & 96 & $5.1 \%$ & \\
\hline $1-3$ & 49 & $15.6 \%$ & 53 & $18.2 \%$ & 168 & $13.2 \%$ & 270 & $14.4 \%$ & \\
\hline $4-7$ & 45 & $14.3 \%$ & 59 & $20.3 \%$ & 211 & $16.6 \%$ & 315 & $15.8 \%$ & \\
\hline $8-11$ & 45 & $14.3 \%$ & 48 & $16.5 \%$ & 228 & $18.0 \%$ & 321 & $17.1 \%$ & \\
\hline $12+$ & 97 & $30.9 \%$ & 89 & $30.6 \%$ & 404 & $31.8 \%$ & 590 & $32.5 \%$ & \\
\hline Not applicable & 5 & $1.5 \%$ & 0 & $0.0 \%$ & 12 & $0.9 \%$ & 17 & $0.9 \%$ & \\
\hline Ignored & 50 & $15.9 \%$ & 32 & $11.0 \%$ & 184 & $14.4 \%$ & 266 & $14.1 \%$ & \\
\hline Number of registered contacts & & & & & & & & & $<0.001$ \\
\hline Contacts non-evaluated & 111 & $11.4 \%$ & 140 & $13.4 \%$ & 883 & $22.3 \%$ & 1134 & $19.0 \%$ & \\
\hline Contacts evaluated & 866 & $88.6 \%$ & 907 & $86.6 \%$ & 3070 & $77.7 \%$ & 4843 & $81.0 \%$ & \\
\hline Total & 977 & $100 \%$ & 1047 & $100 \%$ & 3953 & $100 \%$ & 5977 & $100 \%$ & \\
\hline
\end{tabular}

${ }^{*} \mathrm{p}$-value comparing the pre and post-intervention periods 
Table 2 - Clinical characteristics of study participants in the three study periods. Comparison of pre and post-intervention periods. Palmas, Tocantins State, July 2014 to December 2017.

\begin{tabular}{|c|c|c|c|c|c|c|c|c|c|}
\hline \multirow[t]{2}{*}{ Characteristic } & \multicolumn{2}{|c|}{$\begin{array}{l}\text { Pre-intervention } \\
\text { period }\end{array}$} & \multicolumn{2}{|c|}{ Transition period } & \multicolumn{2}{|c|}{$\begin{array}{l}\text { Post-intervention } \\
\text { period }\end{array}$} & \multicolumn{2}{|c|}{ Total } & \multirow[t]{2}{*}{$p$-value* } \\
\hline & $\mathrm{n}$ & $\%$ & $\mathrm{n}$ & $\%$ & $\mathrm{n}$ & $\%$ & $\mathrm{n}$ & $\%$ & \\
\hline Bacilloscopy & & & & & & & & & $<0.001$ \\
\hline Positive & 55 & $17.5 \%$ & 30 & $10.3 \%$ & 33 & $2.6 \%$ & 118 & $6.2 \%$ & \\
\hline Negative & 101 & $37.2 \%$ & 44 & $15.1 \%$ & 81 & $6.4 \%$ & 226 & $12.0 \%$ & \\
\hline Not done & 148 & $47.1 \%$ & 209 & $71.8 \%$ & 1082 & $82.2 \%$ & 1439 & $76.7 \%$ & \\
\hline Ignored & 10 & $3.2 \%$ & 8 & $2.7 \%$ & 74 & $5.8 \%$ & 92 & $4.9 \%$ & \\
\hline Input type & & & & & & & & & 0.001 \\
\hline New case & 239 & $76.1 \%$ & 214 & $73.5 \%$ & 948 & $77.4 \%$ & 1437 & $76.6 \%$ & \\
\hline Other municipalities & 10 & $3.2 \%$ & 3 & $1.0 \%$ & 40 & $3.1 \%$ & 53 & $2.8 \%$ & \\
\hline Other States & 5 & $1.6 \%$ & 4 & $1.3 \%$ & 32 & $2.5 \%$ & 41 & $2.2 \%$ & \\
\hline Other countries & 0 & $0.0 \%$ & 2 & $0.6 \%$ & 1 & $0.1 \%$ & 3 & $0.1 \%$ & \\
\hline Recurrence & 8 & $2.5 \%$ & 0 & $0.0 \%$ & 2 & $0.1 \%$ & 10 & $0.5 \%$ & \\
\hline Other re-entries & 47 & $14.9 \%$ & 66 & $22.6 \%$ & 188 & $14.8 \%$ & 301 & $16.0 \%$ & \\
\hline Clinical form & & & & & & & & & $<0.001$ \\
\hline Indeterminate & 45 & $14.3 \%$ & 18 & $6.2 \%$ & 23 & $1.8 \%$ & 86 & $4.6 \%$ & \\
\hline Tuberculoid & 22 & $7.0 \%$ & 10 & $3.44 \%$ & 16 & $1.2 \%$ & 48 & $2.5 \%$ & \\
\hline Borderline & 181 & $57.6 \%$ & 227 & $78.0 \%$ & 1068 & $84.0 \%$ & 1476 & $78.7 \%$ & \\
\hline Lepromatous & 45 & $14.3 \%$ & 30 & $10.3 \%$ & 74 & $5.8 \%$ & 149 & $7.9 \%$ & \\
\hline Not classified & 21 & $6.6 \%$ & 6 & $2.0 \%$ & 89 & $7.0 \%$ & 116 & $6.2 \%$ & \\
\hline Degree of disability in diagn & & & & & & & & & $<0.001$ \\
\hline Grade 0 & 156 & $49.6 \%$ & 116 & $39.8 \%$ & 499 & $39.2 \%$ & 771 & $41.1 \%$ & \\
\hline Grade 1 & 108 & $34.3 \%$ & 149 & $51.2 \%$ & 597 & $47.0 \%$ & 854 & $45.5 \%$ & \\
\hline Grade 2 & 32 & $10.2 \%$ & 14 & $4.8 \%$ & 127 & $10.0 \%$ & 173 & $9.2 \%$ & \\
\hline Not evaluated & 18 & $5.7 \%$ & 12 & $4.1 \%$ & 47 & $3.7 \%$ & 77 & $4.1 \%$ & \\
\hline Detection mode & & & & & & & & & $<0.001$ \\
\hline Forwarding & 100 & $31.8 \%$ & 38 & $13.0 \%$ & 180 & $14.1 \%$ & 318 & $16.9 \%$ & \\
\hline Spontaneous & 87 & $27.7 \%$ & 100 & $34.3 \%$ & 355 & $27.9 \%$ & 542 & $28.9 \%$ & \\
\hline Collective examination & 50 & $15.9 \%$ & 26 & $8.9 \%$ & 115 & $9.0 \%$ & 191 & $10.1 \%$ & \\
\hline Examination of contacts & 5 & $1.5 \%$ & 53 & $18.31 \%$ & 313 & $24.6 \%$ & 371 & $19.7 \%$ & \\
\hline Other & 9 & $2.8 \%$ & 5 & $1.7 \%$ & 24 & $1.8 \%$ & 38 & $2.0 \%$ & \\
\hline Ignored & 63 & $20.0 \%$ & 69 & $23.7 \%$ & 283 & $22.2 \%$ & 415 & $22.1 \%$ & \\
\hline \multicolumn{5}{|c|}{ Operational classification during diagnosis } & & & & & $<0.001$ \\
\hline Paucibacillary & 68 & $21.6 \%$ & 28 & $9.6 \%$ & 41 & $3.2 \%$ & 137 & $3.2 \%$ & \\
\hline Multibacillary & 246 & $78.3 \%$ & 263 & $90.3 \%$ & 1229 & $96.7 \%$ & 1738 & $92.7 \%$ & \\
\hline
\end{tabular}

${ }^{*} \mathrm{p}$-value comparing the pre and post-intervention periods

leprosy notifications, of which $1,437(76.6 \%)$ were incident cases. Of those, $948(66 \%)$ were diagnosed in the post-intervention period. Overall, there was a slight predominance of males $(52 \%)$; aged 50 years or more (34.9\%); with mixed ethnicity (63.5\%). The low level of education is noticeable, with more than half of the cases
$(51.7 \%)$ with available data reporting illiteracy or less than 8 years of education. Most cases $(1,738 ; 92.7 \%)$, were in the multibacillary operational classification at the time of diagnosis. The borderline clinical form was the most frequent, comprising 1,476 (78.8\%) cases, of which 1,068 (72.4\%) were diagnosed in the post-intervention period. 
The analysis of disabilities among detected cases showed that $1,027(54.7 \%)$ were diagnosed with some degree of disability; of those, $854(45.5 \%)$ had Grade I (decrease or loss of sensitivity) and $173(9.2 \%)$ had Grade II (installed disabilities and or deformities).

With the exception of education, there were statistically significant differences in the proportions of all other characteristics over the study periods, although not all the differences can be considered epidemiologically significant. The most important differences were: (1) an increase in the proportion of female cases (from $37.5 \%$ in the pre to $50.3 \%$ in the post-intervention); (2) an increase in the proportion of cases with positive sputum smear microscopy (from $47.1 \%$ to $76.7 \%$ ); (3) a reduction in the proportion of grade zero (from $49.6 \%$ to $39.2 \%$ ) with a corresponding increase in the proportion of grade 1 cases (from $34.3 \%$ to $47 \%$ ); (4) an increase in detection by examination of contacts (from $1.5 \%$ to $24.6 \%$ ); (5) an increase in the detection of multibacillary cases (from $78.3 \%$ in the pre to $96.7 \%$ in the post-intervention) and (6) a decrease in the proportion of contacts examined (from $88.6 \%$ to $71.1 \%$ ), despite the large increase in the total number of contacts examined (from 866 to 3,070 ).

When evaluating the operational classification over the evaluated period, by comparing the one performed at diagnosis and the last one noted during the follow-up of the case, the presence of cases that were classified at diagnosis as paucibacillary and were reclassified as multibacillary $(1,57 \%)$ during treatment was observed. Regarding the presence of notifications, the reverse effect (multibacillary cases that were reclassified as paucibacillary) also occurred, although they were much less frequent $(0.38 \%)$. These changes also occurred for children under 15 years of age (5.3\% and $1.51 \%)$.

The median age and median number of contacts registered per case was similar in the pre- and postintervention periods. However, there was a small but statistically significant decrease in the median number of contacts examined per case, from a median of 3 contacts in the pre-intervention period to a median of 2 in the postintervention period $(\mathrm{p}=0.0232)$.

\section{Epidemiological and operational indicators}

The set of indicators in the period from 2007 to 2017 (Table 3) shows an increase in the two latter years of the series in almost all epidemiological indicators, with the exception of " 5 - Proportion of leprosy cases with degree 2 of physical disability at the time of the diagnosis". With regard to operational indicators, half presented values that reflect positive results (evaluated contacts, recurrence and assessment of physical disability in the diagnosis) and the other half (cure, abandonment and healing with assessed physical disability) express values that show a worsening when compared to previous years.

Figures 1 and $2(1=$ indicators 2 and 4; $2=$ indicator 3$)$ shows the monthly progress of the indicators considering data from 2007 to 2017, highlighting with vertical bars the beginning of the intervention period and the end of the transition period. The change in these indicators is well marked by the beginning of the intervention.

In order to analyze the impact of the health intervention, differences in the epidemiological and operational indicators of leprosy were calculated for the pre- and postintervention periods (Table 4). The "general detection rate" in the post-intervention period showed a significant increase of almost 4-fold compared to the pre-intervention period $(\mathrm{p}<0.001)$. The "detection rate in children less than 15 years old" increased more than 3 times $(\mathrm{p}=0.002)$, as well as the "detection rate of grade II cases" $(\mathrm{p}=0.006)$. In addition to these, the indicator "proportion of cure of new cases" decreased significantly ( $p<0.001)$, as well as the number of contacts of new cases evaluated ( $p=0.002)$. The other indicators did not change significantly.

\section{DISCUSSION}

In this study, we analyzed the impact of the Leprosyfree Palmas project on the epidemiological and operational indicators of leprosy in the city of Palmas, Brazil. Cases were predominantly males, with mixed ethnicity, low education, multibacillary classification and borderline clinical form. These characteristics are similar to those reported in the national epidemiological bulletin released by the Ministry of Health, depicting Brazilian data from 2012 to $2016^{12}$. Studies suggest that males are more prone to illness due to a greater exposure to crowds, the absence of specific health programs directed to the gender and having less concern for their own health ${ }^{15,16}$. Low education, as shown in the literature, is one of the factors that directly imply a greater risk of falling ill ${ }^{17}$. In addition, the presence of cases in children under 15 years old confirms that active transmission of the disease is still ongoing ${ }^{18}$.

The increase in the number of detected patients (mainly multibacillary) are likely to have occurred due to an improvement in the diagnostic capacity of healthcare providers, together with the existence of a backload of hidden, undiagnosed oligosymptomatic patients ${ }^{19}$. There were cases in adults and children that had their operational classification changed during treatment. This finding may be due to the improvement of the capacity of health professionals to find signs and symptoms of 
Table 3 - Analysis of the annual epidemiological indicators of leprosy during the total study period in the municipality of Palmas, Tocantins State.

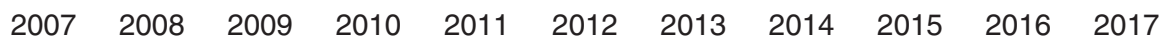

\section{Epidemiological Indicators}

1 - Annual leprosy prevalence rate per 10 thousand inhabitants

\begin{tabular}{|c|c|c|c|c|c|c|c|c|c|c|c|}
\hline Rate (10 K inhab.) & 12.8 & 13.7 & 11.7 & 8.9 & 7.0 & 8.1 & 6.2 & 7.2 & 8.0 & 30.3 & 24.9 \\
\hline
\end{tabular}

2 - Annual detection rate of new leprosy cases per 100 thousand inhabitants

\begin{tabular}{|c|c|c|c|c|c|c|c|c|c|c|}
\hline Rate (100 K inhab.) & 109.9 & 115.8 & 98.1 & 77.5 & 57.8 & 66.9 & 48.9 & 59.2 & 58.7 & $239.4 \quad 184.1$ \\
\hline
\end{tabular}

3 - Annual detection rate of new leprosy cases, in the population from zero to 14 years old, per 100 thousandinhabitants

\begin{tabular}{|c|c|c|c|c|c|c|c|c|c|c|c|}
\hline Rate (100 K inhab.) & 28.7 & 21.8 & 25.9 & 19.6 & 17.6 & 12.8 & 17.9 & 17.9 & 23.1 & 85.1 & 68.1 \\
\hline
\end{tabular}

4 - Rate of new leprosy cases with grade 2 physical disability at the time of diagnosis per 100 thousand inhabitants

\begin{tabular}{|c|c|c|c|c|c|c|c|c|c|c|c|}
\hline Rate (100 K inhab.) & 8.4 & 1.6 & 4.8 & 3.9 & 1.7 & 3.3 & 3.5 & 4.1 & 5.9 & 16.4 & 15.7 \\
\hline
\end{tabular}

5 - Proportion of leprosy cases with grade 2 physical disability at the time of diagnosis among the new cases detected and evaluated in the year

\begin{tabular}{|c|c|c|c|c|c|c|c|c|c|c|c|}
\hline$\%$ & 7.7 & 1.4 & 4.9 & 5.1 & 2.9 & 4.9 & 7.1 & 7.0 & 10.0 & 6.9 & 8.5 \\
\hline \multicolumn{12}{|c|}{$\begin{array}{l}6 \text { - Proportion of leprosy cases cured with grade } 2 \text { physical disability among the cases evaluated at the time of discharge for cur } \\
\text { in the year }\end{array}$} \\
\hline$\%$ & 80.0 & 100.0 & 77.8 & 44.4 & 100.0 & 75.0 & 88.9 & 54.5 & 68.8 & 71.7 & 37.8 \\
\hline \multicolumn{12}{|c|}{7 - Proportion of leprosy cases, according to gender, among the total of new cases } \\
\hline$\%$ male & 50.5 & 57.7 & 62.2 & 62.1 & 61.0 & 63.0 & 51.6 & 63.1 & 62.5 & 47.3 & 49.8 \\
\hline \multicolumn{12}{|c|}{8 - Proportion of cases according to operational classification among the total of new cases } \\
\hline$\%$ multibacillary & 42.3 & 41.8 & 49.2 & 54.2 & 52.2 & 58.0 & 50.8 & 62.4 & 76.3 & 93.4 & 97.2 \\
\hline \multicolumn{12}{|c|}{9 - Detection rate of new cases according to race/ color per 100 thousand inhabitants } \\
\hline White & 30.8 & 29.3 & 17.5 & 15.3 & 11.9 & 9.9 & 9.7 & 11.7 & 8.8 & 35.4 & 26.8 \\
\hline Black & 11.2 & 14.1 & 11.1 & 9.2 & 5.9 & 8.7 & 5.0 & 6.0 & 8.1 & 33.9 & 20.2 \\
\hline Yellow & 3.3 & 1.1 & 1.1 & 0.4 & 0.8 & 0.4 & 0.0 & 1.5 & 1.8 & 14.7 & 18.1 \\
\hline Mixed ethnicity & 63.3 & 70.6 & 67.3 & 52.6 & 37.4 & 45.4 & 33.3 & 38.4 & 38.1 & 152.2 & 116.1 \\
\hline Indigenous & 0.5 & 0.5 & 1.1 & 0.0 & 0.4 & 0.4 & 0.0 & 0.0 & 0.0 & 0.4 & 0.3 \\
\hline Ignored & 0.5 & 0.0 & 0.0 & 0.0 & 1.3 & 2.1 & 0.8 & 1.5 & 1.8 & 2.9 & 2.4 \\
\hline
\end{tabular}

1 - Proportion of leprosy cure among new cases diagnosed in the years of the cohorts

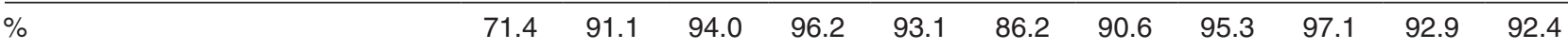

2 - Proportion of leprosy cases in treatment abandonment among new cases diagnosed in the years of the cohorts

\begin{tabular}{llllllllllll}
\hline$\%$ & 28.6 & 4.4 & 4.3 & 2.5 & 5.5 & 1.5 & 3.9 & 2.3 & 0 & 3.6 & 6.8
\end{tabular}

3 - Proportion of examined contacts of new leprosy cases diagnosed in the years of the cohorts

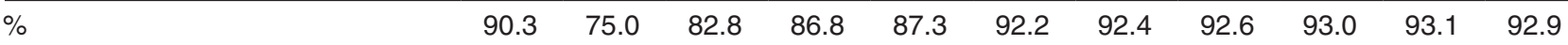

4 - Proportion of recurrence cases among the cases notified in the year

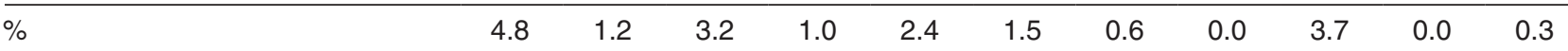

5 - Proportion of new leprosy cases with degree of physical disability assessed at diagnosis

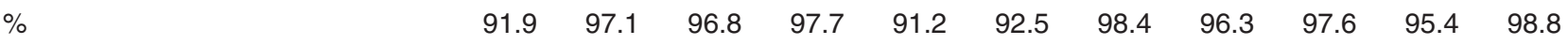

6 - Proportion of cases cured in the year with degree of physical disability assessed among new cases *

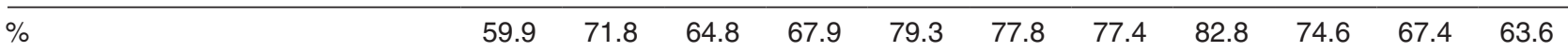

$\mathrm{N}=$ Number of cases per year; \% = Simple frequency of cases per year; ${ }^{*}$ Calculation performed following the cohort parameters of the Ministry of Health, using the sum of the cohort of the two years prior to the year presented. 


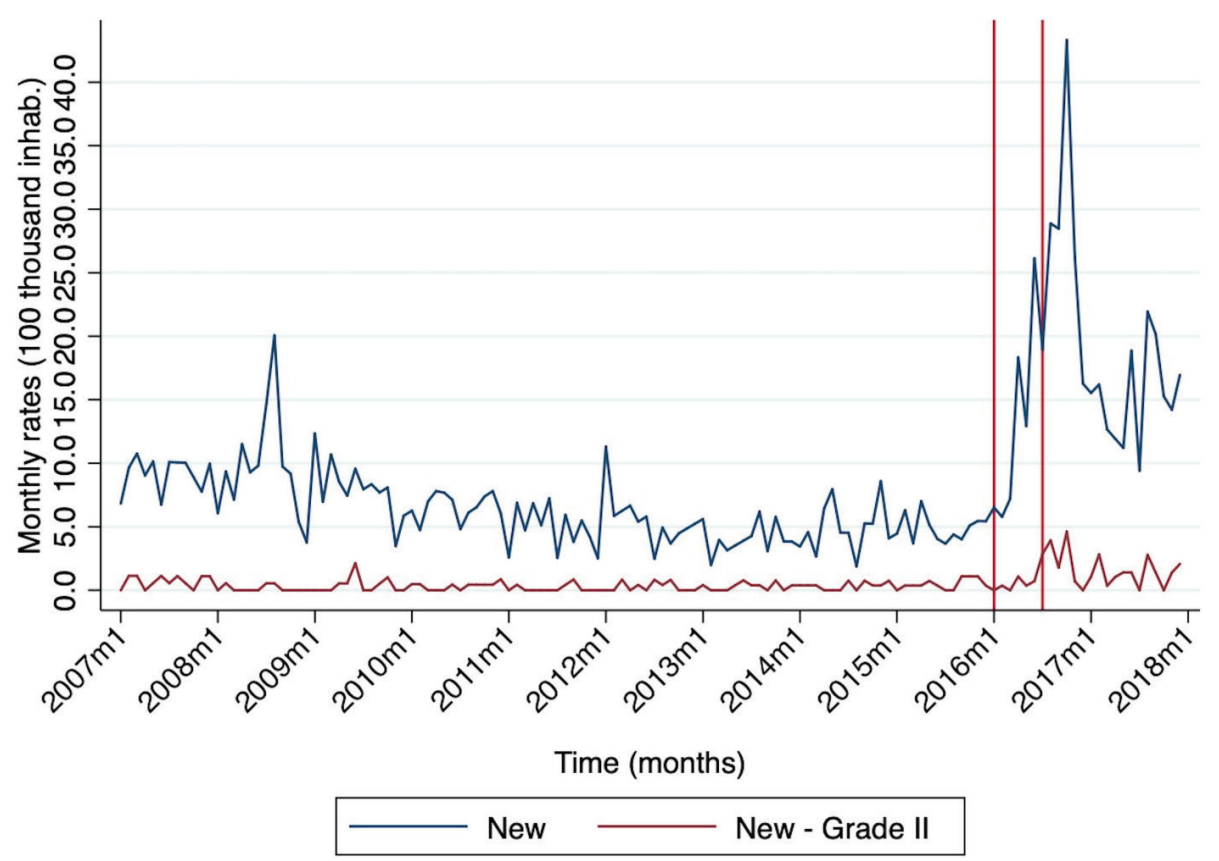

Figure 1 - Monthly rate for new cases and new cases with grade II at all ages. Vertical red bars show the start of the intervention and the end of the transition period.

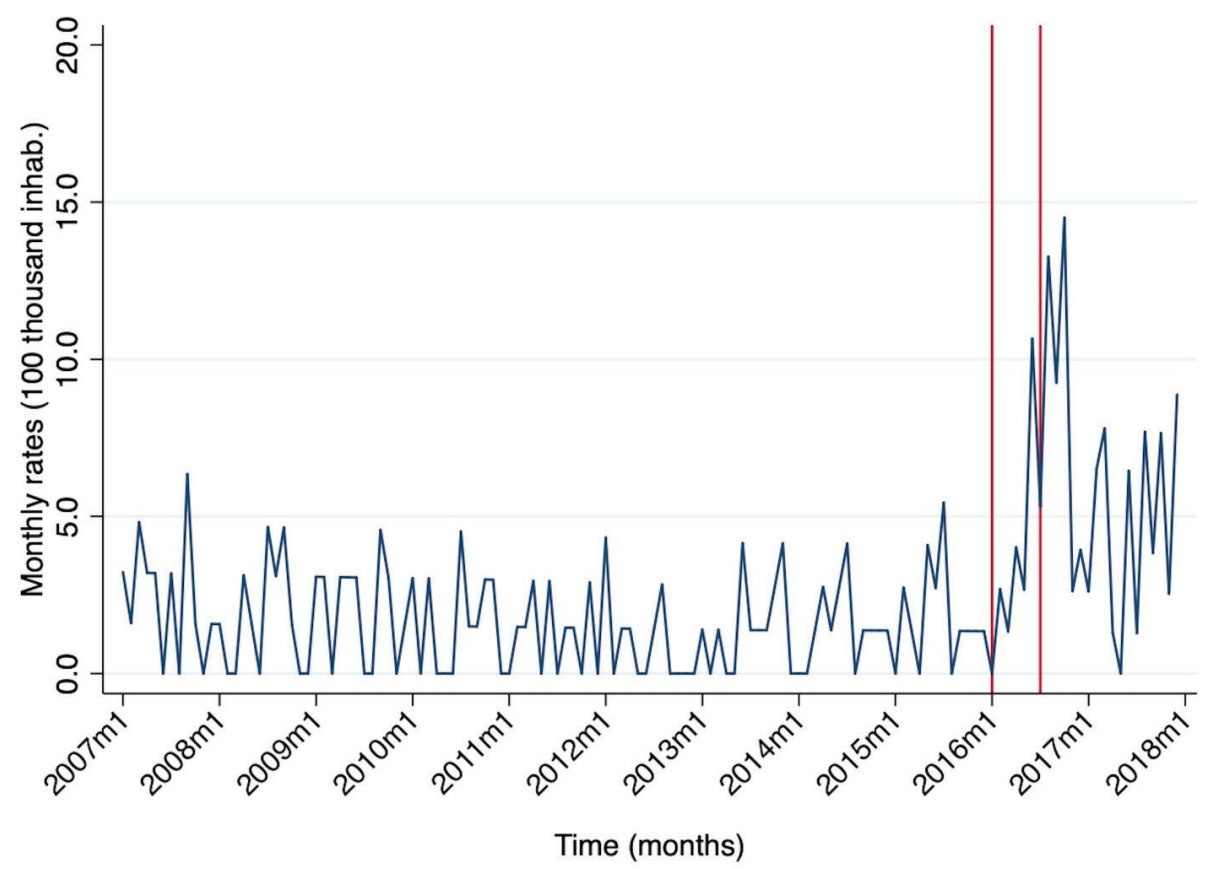

Figure 2 - Monthly rate for new cases under 15 years old. Vertical red bars show the start of the intervention and the end of the transition period.

the disease during patients' reassessments, in addition to the low precision of some diagnostic methods, such as the bacilloscopy ${ }^{20-22}$. Thus, it is essential to carry out detailed clinical assessments aiming to classify the disease appropriately, both at the time of diagnosis and during the follow-up, as treatment changes for different classifications ${ }^{23}$.
The decrease in the number of evaluated contacts followed an increase of more than four-fold in the number of registered contacts, from 977 to 3,953 from the pre- to the post-intervention period. This increase was mainly influenced by two factors. Firstly, a change in the definition of contacts, which has been expanded beyond household contacts by the Ministry of Health of Brazil $;^{4}$ 
Table 4 - Analysis of the main epidemiological and operational indicators of leprosy in the city of Palmas, Tocantins State, in preand post-intervention periods.

\begin{tabular}{|c|c|c|}
\hline EPIDEMIOLOGICAL INDICATORS & Pre- Intervention* & Post- Intervention* \\
\hline $\begin{array}{l}\text { Annual detection rate (detection coefficient) of new leprosy cases per } 100 \text { thousand } \\
\text { inhabitants } \dagger\end{array}$ & 88.3 & 345.6 \\
\hline $\begin{array}{l}\text { Annual detection rate of new leprosy cases, in the population aged zero to } 14 \text {, per } 100 \\
\text { thousand inhabitants } \dagger\end{array}$ & 31.4 & 105.0 \\
\hline $\begin{array}{l}\text { Rate of new leprosy cases with grade } 2 \text { physical disability at the time of diagnosis per } \\
100 \text { thousand inhabitants } \dagger\end{array}$ & 8.9 & 29.5 \\
\hline $\begin{array}{l}\text { Proportion of leprosy cases with grade } 2 \text { physical disability at the time of diagnosis } \\
\text { among the new cases detected and evaluated }\end{array}$ & $10 \%$ & $8.5 \%$ \\
\hline \multicolumn{3}{|l|}{ OPERATIONAL INDICATORS } \\
\hline Proportion of leprosy cure among new cases diagnosed $†$ & $79.5 \%$ & $50.7 \%$ \\
\hline Proportion of leprosy cases in treatment abandonment among new cases diagnosed & $4.6 \%$ & $3.8 \%$ \\
\hline Proportion of examined contacts of new leprosy cases diagnosed ${ }^{\dagger}$ & $88.3 \%$ & $79.6 \%$ \\
\hline $\begin{array}{l}\text { Proportion of cases cured with degree of physical disability assessed among new } \\
\text { leprosy cases }\end{array}$ & $98.4 \%$ & $97.4 \%$ \\
\hline
\end{tabular}

and secondly, because Palmas is a reference for patients coming from other regions, thus making it difficult to assess all contacts, especially family members living in distant areas. However, even with the decrease in the number of contacts, it is important to highlight that the percentage of patients diagnosed in the post-intervention period $(24.6 \%)$ was more than 16 times higher than in the pre-intervention period $(1.5 \%)$. Thus, intersectoral/ intercity/ interstate surveillance actions are essential for controlling leprosy, and the combination of active case-finding with tracing of contacts are key aspects for breaking the transmission chain and avoiding the so called hidden prevalence $7,18,24,25$.

The overall low baseline health conditions and limited access to care in the study population are likely to have enhanced the observed impact on health indicators ${ }^{26}$. The intervention was a set of actions including health education for both, the population and providers, aiming at breaking stigma and prejudice generated by the disease; increasing the availability of medications; encouraging the reintegration of the individual in the society; and building capacity within the healthcare team for a comprehensive treatment of leprosy patients and contacts ${ }^{26}$. The intervention, as performed in Palmas, serves as a model to achieve the elimination of leprosy as a public health problem ${ }^{27}$. In fact, after the success in Palmas, the project has been replicated in Maranhao, Mato Grosso, Para, Pernambuco, Piaui States and elsewhere in the Tocantins State, with the leadership of the Brazilian Ministry of Health in partnership with the Pan American Health Organization and the Nippon Foundation.

The increase in almost all epidemiological indicators reflects the scenario of a disease that had been so far neglected. The paucity of specific actions aimed at this condition masked a substantial hidden prevalence. The slowly decreasing rates of leprosy detection in the municipality of Palmas up to the start of the intervention suggested numbers that approached the elimination of the disease, but hidden cases were nevertheless abundant in the community ${ }^{19}$. This scenario is similar to the ones found in countries like India and Nepal, in which mandatory notification has been withdrawn after the elimination goals were reached; current official reports show a low prevalence of leprosy, which are unfortunately likely to be due to underreporting of cases and decreased active surveillance of the disease $e^{9,28-33}$.

Palmas remains a hyper-endemic municipality for leprosy. The sudden increase in epidemiological indicators in 2016, especially the "general detection rate and in children under 15 years old" and the "rate of cases with grade 2 disability", are a consequence of existing undiagnosed cases in the community. Leprosy has a slow progression with few signs and symptoms that, if reported to health professionals without the necessary training and skills, could be misdiagnosed with other conditions that present with similar symptoms (diabetic neuropathy, peripheral neuropathy, sciatic neuralgia ${ }^{1,34}$. In addition, the increase in the "rate of cases with grade 2 disability" also reinforces the occurrence of late diagnosis, emphasizing the importance of active case-finding strategies ${ }^{4}$.

Among the epidemiological indicators, the "proportion of leprosy cases with grade 2 disability at the time of diagnosis" was the only one that did not increase in the last two years of the study. It is possible that this may 
be due to leprosy-specific actions that took place in the municipality prior to the study intervention, such as the Novartis health care itinerant bus carried out at the end of 2014, and the so called Purple January associated with the intensification of surveillance actions at the beginning of $2015^{28}$. These initiatives may have been effective in training local healthcare providers in the detection of more advanced and severe cases in the community, resulting in an increase in the proportion of cases in 2015. Nevertheless, even though this indicator failed to increase compared to its peak in 2015, the municipality presented its second highest value in 2017, which reinforces the impact of the intervention on this indicator.

According to the study carried out in 2018 in Bahia State, the increase in cases of disease recurrence express a low effectiveness of leprosy control, thus the decrease or even absence of cases of disease recurrence in 2016, presented in our results, by the indicator "Proportion of cases of recurrence among the cases notified in the year", express the positive influence of the on-site actions carried out in Palmas ${ }^{35}$. Recurrent cases require a specific evaluation which is usually done by the reference professional of the municipality ${ }^{4}$. With the improvement of the ability to evaluate and treat patients due to the intervention, not only the referral, but also the professionals of the basic units, started to correctly classify the patients. By doing so, these professionals may have become more capable to differentiate recurrence from treatment reaction and therefore to adequately treat each case $^{1,36}$.

Considering the prioritized epidemiological indicators compared in the pre- and post-intervention, there was a statistically significant increase of all items, particularly of the "general detection rate" and the "detection rate of under 15 years old". Compared to a similar study conducted in Juazeiro/Bahia in 2017, Palmas had favorable results in a larger number of indicators ${ }^{37}$.

As for operational indicators, the significant decrease in the proportion of cure, as compared in the pre- and post-intervention period, is due to the sudden increase in the number of cases. A structured network of services is required in order to follow leprosy patients in the course of treatment ${ }^{38}$. We acknowledge that the health network needs time to incorporate all these newly diagnosed patients, and additional time is needed for this to be expressed as an increase in the proportion of cure. In addition, the indicator is calculated as a cohort, so that its numerical results can only appear two years after the intervention. Another important factor interfering with the proportion of cure is the fact that Palmas is a reference of "diagnostic tourism" for several neighbor regions. As these traveling patients often return to their place of origin, follow up until "discharge by cure" becomes challenging.

One of the principles for developing effective health actions is the health coverage offered by a municipality: Palmas has a coverage of about $80 \%{ }^{39}$. Studies suggest the greater coverage of the Family Health Strategy is associated with higher annual detection of new cases and hidden prevalence ${ }^{40,41}$. In addition, regions that have more than $60 \%$ coverage are almost 3 times more likely to include in their package of care actions to prevent leprosy ${ }^{42}$. According to a study published in 2008 , the ability to diagnose leprosy is directly related to the access to health care services ${ }^{43}$.

Importantly, as presented by Nsagha et al. ${ }^{27}$, the main interventions carried out around the world to fight leprosy aim at drug actions, which are important steps for the elimination but do not address the social and economic issues, stigma and social prejudice and the prevention of disabilities, and these are major concerns and central elements for the elimination of the disease. Another important factor is the direct interaction with the population to reduce the misinformation about the disease. Patients with leprosy and their families must be aware that the disease is likely to persist unless treated; that active transmission may be occurring and that there is a cure with medication and proper care ${ }^{43}$.

This study has some limitations: a) Data were retrieved from secondary databases that depend on the professionals being properly filled out; $b$ ) There was a rotation of health professionals in the assistance network.

In summary, our study showed an impressive impact of health care interventions aimed at increasing early diagnosis and adequate management carried out in a hyperendemic municipality in Brazil. We suggest that similar interventions are incorporated into the health care system. Additionally, it is necessary to strengthen the epidemiological surveillance; invest in the implementation of laboratory techniques and complementary exams; develop better integration of healthcare networks; and offer recurrent training for healthcare providers on diagnostics and care. Without a comprehensive approach, it will be impossible to reach the goal of eliminating leprosy as a public health problem over the next decades.

\section{ACKNOWLEDGMENTS}

The authors express their gratitude to everyone involved in the development and execution of the project.

\section{CONFLICT OF INTERESTS}

The authors declare no conflict of interests. 


\section{FINANCIAL SUPPORT}

The study had no specific funding

\section{REFERENCES}

1. Brasil. Ministério da Saúde. Secretaria de Políticas de Saúde. Departamento de Atenção Básica. Guia para o controle da hanseníase. Brasília: Ministério da Saúde; 2002. [cited 2020 Sep 2]. Available from: http://bvsms.saude.gov.br/bvs/ publicacoes/guia_de_hanseniase.pdf

2. Brasil. Ministério da Saúde. Secretaria de Vigilância em Saúde. Departamento de Vigilância Epidemiológica. Doenças infecciosas e parasitárias: guia de bolso. $5^{\mathrm{a}}$ ed. ampl. Brasília: Ministério da Saúde; 2005. [cited 2020 Sep 2]. Available from: https:// bvsms.saude.gov.br/bvs/publicacoes/guia_bolso_5ed2.pdf

3. Machado MP, Silva RC, Nogueira AL, Barros CV. Situação endêmica da hanseníase no período de 2006 a 2011 no município de Aparecida de Goiânia - GO. Rev Univ Vale do Rio Verde. 2014;12:316-22.

4. Brasil. Ministério da Saúde. Secretaria de Vigilância em Saúde. Departamento de Vigilância das Doenças Transmissíveis. Diretrizes para a vigilância, atenção e eliminação da hanseníase como problema de saúde pública: manual técnico-operacional. Brasília: Ministério da Saúde; 2016. [cited 2020 Sep 2]. Available from: http://lproweb.procempa.com.br/pmpa/ prefpoa/cgvs/usu_doc/diretrizes_hanseniase.pdf

5. Duarte-Cunha M, Souza-Santos R, Matos HJ, Oliveira ML. Aspectos epidemiológicos da hanseníase: uma abordagem espacial. Cad Saude Publica. 2012;28:1143-55.

6. Ribeiro Junior AF, Vieira MA, Caldeira AP. Perfil epidemiológico da hanseníase em uma cidade endêmica no Norte de Minas Gerais. Rev Bras Clin Med. 2012;10:272-7.

7. Alves ED, Ferreira TL, Nery I, organizadores. Hanseníase: avanços e desafios. Brasília: Universidade de Brasília; 2014. [cited 2020 Sep 2]. Available from: http://www.morhan.org. br/views/upload/hanseniaseavancoes.pdf

8. Bravin HM, Nascimento AP. Busca ativa a pacientes portadores de hanseníase no município de Primavera do Leste - MT. Connectionline. 2007;2:9-13.

9. World Health Organisation. Global leprosy update, 2016: accelerating reduction of disease burden. Wkly Epidemiol Rec. 2017;92:501-19.

10. Opromolla DV, Ura S. Atlas de hanseníase. Bauru: Instituto Lauro de Sousa Lima; 2002.

11. Alves CR, Ribeiro MM, Melo EM, Araújo MG. Teaching of leprosy: current challenges. An Bras Dermatol. 2014;89:454-9.

12. Brasil. Ministério da Saúde. Secretaria de Vigilância em Saúde. Caracterização da situação epidemiológica da hanseníase e diferenças por sexo, Brasil, 2012-2016. Bol Epidemiol. 2018;49:1-10.
13. Brasil. Ministério da Saúde. Sala de Apoio à Gestão Estratégica. Morbidade: hanseníase. [cited 2019 Sep 2]. Available from: https://sage.saude.gov. $\mathrm{br} /$ ?link=paineis $/$ hanseniase $/$ corpao $\& \mathrm{flt}=$ false $\&$ param $=\mathrm{co}_{-}$ agravo $=4 \&$ no_agravo $=\mathrm{Hansen} \% \mathrm{C} 3 \% \mathrm{AD}$ ase \&no_ a gravo $1=\mathrm{H}$ anse $\%$ C $3 \%$ A D a s e $\% 20-\% 20$ Taxa\% 20 por $\% 20100.000 \% 20 \% 20 \mathrm{hab} /$ ano \& no_ agravo $2=$ Hansen $\%$ C3\% ADase $\% 20-\% 20$ Percentual $\% 20$ entre $\% 20$ casos $\% 20$ novos \& tipo_agravo $=$ morbidade $\&$ ufibge $=17 \&$ municipioibge $=172100 \& \mathrm{cg}=\& \mathrm{tc}=\& \mathrm{re}$ giao $=\& \mathrm{rm}=\& \mathrm{qs}=\&$ idPagina $=50$

14. Brasil. Ministério da Saúde. Secretaria de Gestão do Trabalho e da Educação na Saúde. Departamento de Gestão da Educação em Saúde. Política nacional de educação permanente em saúde. Brasília: Ministério da Saúde; 2009. [cited 2020 Sep 2]. Available from: http://bvsms.saude.gov.br/bvs/publicacoes/ politica_nacional_educacao_permanente_saude.pdf

15. Bittencourt LP, Carmo AC, Leão AM, Clos AC. Estigma: percepção sociais reveladas por acometidos por hanseníase. Rev Enferm UERJ . 2010;18:185-90.

16. Moura AD, Albuquerque ER, Chaves ES, Souza AR, Lima GG, Chaves CS. Perfil dos portadores de hanseniase de um centro de referencia de um estado brasileiro. Rev Enferm UERJ. 2016;24:e9625.

17. Souza EA, Ferreira AF, Boigny RN, Alencar CH, Heukelbach J, Martins-Melo FR, et al. Leprosy and gender in Brazil: trends in an endemic area of the Northeast region, 2001-2014. Rev Saude Publica. 2018;52:20.

18. Monteiro LD, Lopes LS, Santos PR, Rodrigues AL, Bastos WM, Barreto JA. Tendências da hanseníase após implementação de um projeto de intervenção em uma capital da Região Norte do Brasil, 2002-2016. Cad Saude Publica. 2018;34:e0007818.

19. Monteiro LD, Melo FR, Brito AL, Lima MS, Alencar CH, Heukelbach J. Tendências da hanseníase no Tocantins, um estado hiperendêmico do Norte do Brasil, 2001-2012. Cad Saude Publica. 2015;31:971-80.

20. Bhushan P, Sardana K, Koranne RV, Choudhary M, Manjul P. Diagnosing multibacillary leprosy: a comparative evaluation of diagnostic accuracy of slit-skin smear, bacterial index of granuloma and WHO operational classification. Indian J Dermatol Venereol Leprol. 2008;74:322-6.

21. Gift N, Geetha J, Joseph R. Validity of the WHO operational classification and value of other clinical signs in the classification of leprosy. Int J Lepr Other Mycobact Dis. 2004;72:278-83.

22. Cavalcanti AA, Lucena-Silva N, Montarroyos UR, Albuquerque PM. Concordance between expected and observed bacilloscopy results of clinical forms of leprosy: a 6-year retrospective study in Recife, State of Pernambuco, Brazil. Rev Soc Bras Med Trop. 2012;45:616-9.

23. Santos VS, Mendonça-Neto PT, Raposo OF, Fakhouri R, Reis 
FP, Feitosa VL. Evaluation of agreement between clinical and histopathological data for classifying leprosy. Int J Infect Dis. 2013;17:189-92.

24. Stafin I, Guedes VR, Mendes SU. Diagnóstico precoce de hanseníase e ações estratégicas para a sua detecção. Rev Patol Tocantins. 2018;5:67-73.

25. Souza CF, Slaibi EB, Pereira RN, Francisco FP, Bastos ML, Lopes MR, et al. A importância do diagnóstico precoce da hanseníase na prevenção de incapacidades. Hansen Int. 2010;35:61-6.

26. Organização Pan-Americana da Saúde. Indicadores básicos de saúde no Brasil: conceitos e aplicações. 2 ${ }^{\mathrm{a}}$ ed. Brasília: OPAS; 2008. [cited 2020 Sep 2]. Available from: http://tabnet.datasus. gov.br/tabdata/livroidb/2ed/indicadores.pdf

27. Nsagha DS, Bamgboye EA, Assob JC, Njunda AL, Kamga HL, Bissek AC, et al. Elimination of leprosy as a public health problem by 2000 AD: an epidemiological perspective. Pan Afr Med J. 2011;9:4.

28. Mangeard-Lourme J, Singh A, Singh RK, Parasa J, Arquer GR. Enhanced active case-finding, identifying leprosy cases missed by recent detection campaigns in Munger District, Bihar, India. Lepr Rev. 2017;88:452-62.

29. Mandavilli A. In India, a renewed fight against leprosy. The New York Times. 2019 Apr 23: Section D, Page 1. [cited 2020 Sep 2]. Available from: https://www.nytimes.com/2019/04/17/ health/leprosy-india-disease.html

30. Menon R. Do more detected cases mean leprosy is making a comeback in India? Experts, government differ. IndiaSpend. 2019 Jan 4. [cited 2020 Sep 2]. Available from: https://www. indiaspend.com/leprosy-is-making-a-comeback-in-india-butthe-govt-wants-to-deny-it/

31. Ratcliffe R. The harder you look the more you find: Nepal's hidden leprosy. The Guardian. 2019 Apr 22. [cited 2020 Sep 2]. Available from: https://www.theguardian.com/globaldevelopment/2019/apr/22/nepal-hidden-leprosy

32. Fundación io. Lepra en Nepal: datos del 2018. [cited 2020 Sep 2]. Available from: https://fundacionio.com/2020/01/15/lepraen-nepal-datos-del-2018

33. Shiva RK, Geetika KC, Gyawali P, Singh M, Sijapati MJ. Leprosy - eliminated and forgotten: a case report. J Med Case Rep. 2019;13:276.
34. Rinaldi A. The global campaign to eliminate leprosy. PLoS Med. 2005;2:e341.

35. Almeida KT, Menezes AM, Alves KA, Carmo Filho JR, Costa AK. Recidiva da hanseníase entre os anos 2005-2015. Rev Enferm UFPE on line. 2018;12:2528-34.

36. Waters M. Distinguishing between relapse and late reversal reaction in multidrug (MDT)-treated BT leprosy. Lepr Rev. 2001;72:250-3.

37. Souza CD, Matos TS. Análise de tendência dos indicadores de monitoramento e avaliação da qualidade dos serviços de hanseníase em município prioritário do Nordeste brasileiro. Rev Bras Pesq Saude. 2017;19:74-83.

38. Atkinson S, Haran D. Back to basics: does decentralization improve health system performance? Evidence from Ceara in north-east Brazil. Bull World Health Organ. 2004;82:822-7.

39. Tocantins. Governo do Estado. Secretaria de Estado da Saúde. Plano Estadual de Educação Permanente em Saúde do Tocantins: 2020-2023. Palmas: Secretaria de Estado da Saúde; 2018. [cited 2020 Sep 2]. Available from: https://central3. to.gov.br/arquivo/424965/

40. Nery JS, Pereira SM, Rasella D, Penna ML, Aquino R, Rodrigues LC, et al. Effect of the Brazilian conditional cash transfer and primary health care programs on the new case detection rate of leprosy. PLoS Negl Trop Dis. 2014;8:e3357.

41. Siddiqui MR, Velidi NR, Pati S, Rath N, Kanungo AK, Bhanjadeo $\mathrm{AK}$, et al. Integration of leprosy elimination into primary health care in Orissa, India. PLoS One. 2009;4:e8351.

42. Kessler M, Thumé E, Duro SM, Tomasi E, Siqueira FC, Silveira DS, et al. Ações educativas e de promoção da saúde em equipes do Programa Nacional de Melhoria do Acesso e da Qualidade da Atenção Básica, Rio Grande do Sul, Brasil. Epidemiol Serv Saude. 2018;27:e2017389.

43. Penna ML, Oliveira ML, Carmo EH, Penna GO, Temporão JG. Influência do aumento do acesso à atenção básica no comportamento da taxa de detecção de hanseníase de 1980 a 2006. Rev Soc Bras Med Trop. 2008;41 Suppl 2:6-10. 